\title{
PENYULUHAN KONSELING MITOS DAN FAKTA MASA NIFAS
}

\author{
Yuli Suryanti', Lara Restianda ${ }^{2}$, Sinta Arzella ${ }^{3}$ \\ ${ }^{1,2,3)}$ Program Studi D III Kebidanan, Stikes Mitra Adiguna Palembang \\ e-mail: yulisuryanti21@gmail.com
}

\begin{abstract}
Abstrak
Penyuluhan ini bertujuan untuk menunjukkan pentingnya pengetahuan mitos dan fakta masa nifas pada ibu-ibu Kelurahan Talang Jambe terlebih dimasa pandemi Covid-19. Masa Nifas merupakan masa kritis bagi ibu pasca melahirkan. Ketidaksiapan secara fisik, psikis, mental dan spiritual dalam menghadapi masa ini akan membuat masa nifas berjalan tidak normal. Masa nifas tidak kalah penting dengan masamasa ketika hamil, karena pada masa nifas ini organ-organ reproduksi sedang mengalami proses pemulihan setelah terjadinya proses kehamilan dan persalinan. Untuk menyampaikan pesan atau materi penyuluhan biasanya bahasa yang digunakan ialah bahasa yang mudah dimengerti dan dipahami sehingga tidak terlalu sulit untuk dimengerti oleh sasaran atau objek penyuluhan. Media yang biasanya digunakan dalam penyuluhan seperti media cetak, dan media elektronik. Kesimpulan dalam kegiatan ini yaitu kegiatan penyuluhan tentang Mitos dan fakta masa nifas berhubungan dengan peningkatan tingkat pengetahuan. Berdasarkan hasil penelitian ini maka perlu dilakukan kegiatan promosi kesehatan secara berkala.
\end{abstract}

Kata Kunci: Nifas, Mitos,Fakta

\begin{abstract}
This counseling aims to show the importance of knowledge of the myths and facts of the postpartum period for Kelurahan Talang Jambe mothers, especially during the Covid-19 pandemic. Postpartum period is a critical period for postpartum mothers. Unpreparedness physically, psychologically, mentally and spiritually in facing this period will make the postpartum period run abnormally. maternity. To convey messages or extension material, the language used is usually easy to understand and understand so that it is not too difficult for the target or object of the extension to understand. Media is an important means of extension. Media that are usually used in extension such as print media and electronic media. The conclusion in this study is that the activity of counseling about the myths and facts of the postpartum period is related to an increase in the level of knowledge. Based on the results of this study, it is necessary to carry out regular health promotion activities.
\end{abstract}

Keywords: Postpartum, Myths, Fact

\section{PENDAHULUAN}

Penyuluhan ini dilaksanakan dalam rangka memberikan informasi terkait tentang pentingnya pengetahuan mengenai fakta dan mitos dalam masa nifas pada ibu-ibu di Kelurahan Kelurahan Talang Jambe. Dengan kegiatan ini diharapkan ibu-ibu di Kelurahan Talang Jambe lebih mengerti mengenai fakta dan mitos dalam masa nifas. Masa nifas (puerperineu) adalah masa yang mulai setelah plasenta lahir dan berakhir 6 minggu. pada masa nifas seluruh organ kandungan akan pulih kembali, seperti dalam keadaan semula sebelum hamil dalam waktu 3 bulan setelah bersalin. (Ika Murtiyarini, 2020) Nifas disebut juga dengan masa kritis bagi ibu pasca melahirkan karena mengalami perubahan pada tubuh dan mengalami ketidaksiapan secara fisik, psikis, mental dan spiritual dalam menghadapi masa ini akan membuat masa nifas berjalan tidak normal. (Jiarti Kusbandiyah 2020) Masa nifas tidak kalah pentingnya dengan masa ketika hamil, karena pada saat ini organ-organ reproduksi sedang mengalami proses pemulihan setelah terjadinya proses kehamilan dan bersalin. Masa nifas dapat dibagi menjadi 3 bagian yaitu pasca nifas, masa nifas dini, dan masa nifas lanjut, yang masing-masing memiliki ciri khas tertentu. Pasca nifas adalah masa setelah persalinan sampai 24 jam setelahnya (0-24 jam setelah Persalinan). Masa nifas dini adalah masa permulaannya nifas yaitu 1 hari sesudah melahirkan sampai 7 hari setelahnya (1 
minggu pertama). Masa nifas lanjut adalah 1 minggu sesudah persalinan sampai dengan 6 minggu setelah persalinan. (Ika Murtiyarini, 2020).

Asupan nutrisi yang baik dapat membantu proses pemulihan pada masa nifas dan membantu memperlancar produksi ASI. (Tetti Solehati,2020) Nutrisi yang diperlukan oleh ibu nifas seperti protein, karbohidrat, lemak dan vitamin. Ibu nifas yang masih menganut mitos tentang pantang makanan seperti tidak boleh makan makanan yang amis-amis seperti ikan, telur dan daging akan memperlama proses pemulihan pada masa nifas.(Deni Imam, 2019) Asupan protein yang baik dapat membantu penyembuhan luka baik luka persalinan normal maupun luka sectio caesarea. (Suryanti, 2020).

Post Natal Care (PNC) dipromosikan oleh World Healty Organization (WHO) Secara khusus, dan merekomendasikan ibu dan bayi mendapatkan PNC awal dalam 24 jam pertama setelah persalinan dan minimal tiga kunjungan tambahan PNC dalam waktu 48-72 jam, dan 7-14 hari, dan 6 minggu setelah melahirkan. (Popy Apriyanti 2020) Pelayanan kesehatan yang diberikan untuk ibu nifas bertujuan untuk mendeteksi komplikasi pada masa nifas, penanganan dan rujukan terhadap kejadian tak diinginkan yang bisa terjadi, kesehatan secara umum, kebersihan personal, gizi yang dibutuhkan, melakukan perawatan bayi seperti perawatan tali pusat untuk mencegah terjadinya infeksi, memberikan ASI, KB dan melakukan imunisasi. Mutu pelayanan dasar yang harus diberikan pemerintah kepada masyarakat dapat dilihat dari capaian SPM yang merupakan pencapaian target sebagai hasil kinerja pemerintah maka harus $100 \%$ setiap tahunnya. (Septi Maisyaroh , 2020).

Target global MDGs (Development Goals) menurunkan angka kematian ibu (AKI) menjadi 102 per 100.000 kelahiran hidup pada tahun 2017. (Septi Maisyaroh, 2020) AKI di Indonesia pada Tahun 2018 sebesar 75,78 per 100 ribu kelahiran hidup menurun dibandingkan dengan AKI tahun 2017 sebanyak 88,05 per 100 ribu kelahiran hidup. AKI di Provinsi Jawa Tengah pada tahun 2017 sebesar 127.96 per 100 ribu kelahiran hidup, dengan jumlah kematian ibu terjadi pada masa nifas sebanyak 45,90\%. Angka kematian ibu dan bayi menjadi tolak ukur dalam menilai derajat kesehatan suatu bangsa, oleh karena itu pemerintah harus mampu menekankan untuk menurunkan angka kematian ibu dan bayi melalui programprogram kesehatan atau penyuluhan-penyuluhan yang berkala. Dalam pelaksanaan program kesehatan dan penyuluhan sangat dibutuhkan sumber daya manusia yang kompeten, sehingga apa yang menjadi tujuan dapat tercapai.

Pelayanan kesehatan pada masa nifas yang bermutu dan berkualitas maka harus melakukan peningkatan standar menjaga mutu sebagai titik capai dalam memperbaiki dan meningkatkan kinerja pelayanan nifas oleh bidan. Kinerja adalah hasil kerja secara kualitas dan kuantitas yang dapat dicapai oleh seseorang dalam menjalankan setiap tugasnya yang sesuai dengan tanggung jawab yang telah diterimanya. Menurut teori Gibson ada tiga variabel yang dapat mempengaruhi kinerja dan perilaku yakni variabel individu terdiri dari kemampuan dan keterampilan, latar belakang serta demografi, variabel psikologis yang terdiri dari persepsi, sikap, kepribadian, belajar dan motivasi, serta variabel organisasi yang terdiri SDM, kepemimpinan, imbalan, struktur, supervisi, beban kerja dan desain pekerjaan.Hasil yang diharapkan dari setiap perilaku adalah prestasi dalam melaksanakan pekerjaan sehingga pelayanan yang diberikan bermutu (Septi Maisyaroh , 2020).

\section{METODE}

Rancangan kegiatan pengabdian masyarakat ini adalah berupa penyuluhan dengan pengumpulan data dilakukan dengan metode observasi kepada seluruh peserta. Kegiatan dibagi menjadi 3 fase, yaitu fase orientasi, kerja dan terminasi. Fase orientasi meliputi tahap perkenalan, penyampaian tujuan, Fase kerja meliputi pengaturan penyampaian materi dan konseling secara online. Fase ketiga adalah terminasi yaitu evaluasi jalannya suatu kegiatan. Ada 2 macam evaluasi, yang pertama evaluasi subyektif dengan menanyakan perasaan peserta setelah semua sesi selesai dilaksanakan, serta evaluasi obyektif dengan menanyakan kembali materi mengenai Mitos dan Fakfa masa nifas. Sasaran kegiatan ini adalah ibu-ibu di Kelurahan Talang Jambe, khususnya para ibu-ibu pasca melahirkan. Alat yang digunakan dalam kegiatan penyuluhan adalah laptop dan power point. Kegiatan ini dilaksanakan dalam satu periode waktu yaitu pada tanggal 23 November 2020 di Stikes Mitra Adiguna. Kegiatan ini dilakukan secara daring menggunakan media zoom dan live Instagram. 


\section{HASIL DAN PEMBAHASAN}

Penyuluhan yang dilaksanakan di Stikes Mitra Adiguna ini adalah penyuluhan dengan memanfatkan media daring sebagai sarana pemaparan materi penyuluhan. Salah satu penerapan penyuluhan yang dilakukan adalah dengan media zoom dan instagram. Media ini memiliki keuntungan dan kemudahan dalam hal mengembangkan bahan dan mempermudah dalam memaparkan materi. Hasil dan pembahasan dalam penyuluhan di Kelurahan Talang Jambe ini akan dijelaskan berdasarkan tahapan-tahapan berikut.

\section{A. Tahap Persiapan}

Pada tahap persiapan, penyuluh merencanakan kegiatan dengan melaksanakan tahapan observasi kegiatan dan media yang digunakan. Hal-hal yang dilakukan oleh penyuluh adalah sebagai berikut :

1. Membuat rencana kegiatan penyuluhan di Kelurahan Talang Jambe

2. Membuat rencana mengenai sistem penyuluhan

3. Membuat rencana mengenai alat yang akan digunakan dalam penyuluhan

4. Membuat rencana mengenai sasaran penyuluhan

5. Membuat rencana agar ibu-ibu di Kelurahan Talang Jambe dapat mengikuti penyuluhan dengan baik dan berperan aktif selama sesi penyuluhan.

Tahap-tahap berikut dibuat agar mempermudah penyuluhan, dimana dimasa pandemi ini kita berusaha untuk mencegah terjadinya penyebaran covid-19, Maka dari itu penyuluhan ini dilakukan sesuai dengan standar protokol kesehatan dan diharapkan semua peserta penyuluhan dapat melaksanakannya dengan baik. Dengan demikian, perencanaan dalam kegiatan ini dilakukan semaksimal dan seefektif mungkin menyesuaikan dengan situasi dan kondisi pandemi Covid-19.

\section{B. Tahap Kegiatan}

Setelah tahap persiapan sesuai dengan program penyuluhan, tahap selanjutnya adalah tahap kegiatan. Hal yang utama dari tahap kegiatan ini adalah penyampaian materi tentang Mitos dan Fakta masa nifas pada ibu-ibu Kelurahan Talang Jambe. Diharapkan kegiatan penyuluhan ini dapat meningkatkan pengetahuan ibu mengenai masa nifas.

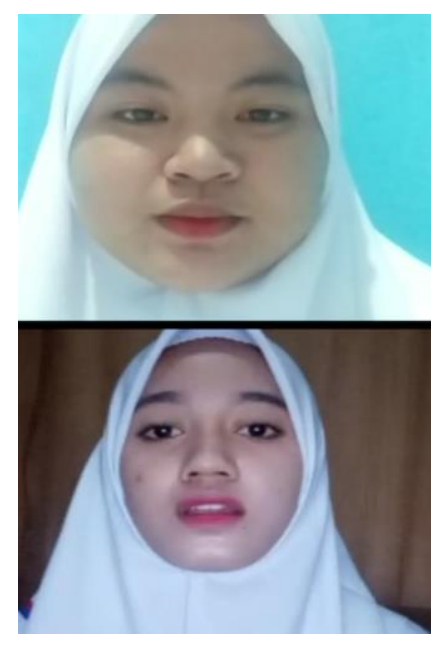

\section{Gambar 1. Penyuluhan Mitos Dan Fakta Masa Nifas}

Dalam penyuluhan ini, ada beberapa hal yang dilakukan oleh penyuluh. Pertama, penyuluh memberikan materi Mitos dan Fakta masa nifas dengan bantuan media: Laptop, dan power point. Pada bagian ini hal-hal yang dijelaskan oleh penyuluh adalah sebagai berikut :

1. Pengertian masa nifas dan waktu lamanya masa nifas

2. Memaparkan materi mengenai mitos-mitos masa nifas

3. Memaparkan materi mengenai fakta-fakta masa nifas 
4. Kegiatan konseling online bagi ibu-ibu pasca persalinan

5. Kegiatan penyuluhan ini harus dikembangkan dan dilakukan secara berkala

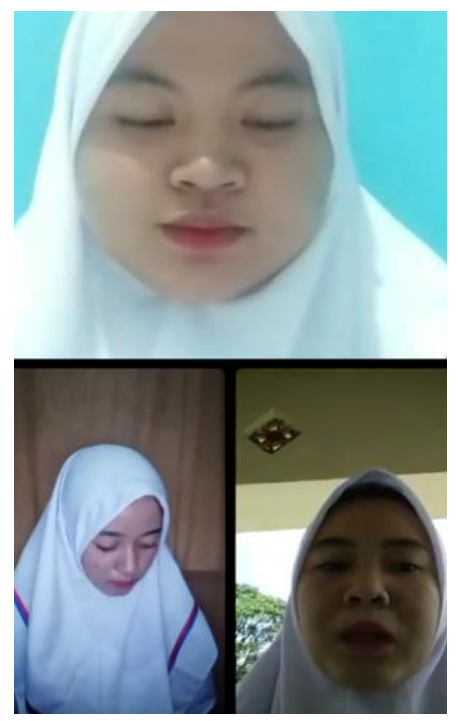

Gambar 2. Penyuluhan Konseling Mitos Dan Fakta Masa Nifas Secara Daring Media Zoom dan Instagram

Kedua, penyuluh memberikan informasi terkait dengan informasi mengenai pengetahuan masa nifas. Berdasarkan hasil kegiatan penyuluhan, ada beberapa hal yang harus dilakukan ibu-ibu agar memperluas pengetahuan mengenai masa nifas, yakni sebagai berikut :

1. Membaca buku-buku mengenai Persalinan

2. Membaca buku-buku mengenai masa nifas

3. Melakukan konseling kepada tenaga kesehatan

4. Lebih berperan aktif menggunakan media sosial untuk mengetahui hal-hal mengenai persalinan dan masa nifas.

Berdasarkan penjelasan diatas dapat disimpulkan bahwa kegiatan penyuluhan dengan materi mitos dan fakta dalam masa nifas dapat meningkatkan pengetahuan ibu pasca persalinan mengenai hal-hal yang harus dilakukan dan tidak perlu dilakukan dalam masa nifas. Penyuluhan ini harus dapat dilakukan demi mencegah terjadinya kesalahan asuhan kepada ibu-ibu pasca persalinan. Hal ini terbukti masih banyaknya ibu-ibu percaya akan mitos-mitos mengenai masa nifas.

\section{Evaluasi Kegiatan}

Tahap ketiga pada kegiatan penyuluhan ini adalah tahap evaluasi kegiatan. Berdasarkan kegiatan ini, masih banyak yang harus diperbaiki dan dibenahi dalam melakukan penyuluhan mengenai mitos dan fakta tentang masa nifas,karena masih banyaknya ibu-ibu menyakini mengenai mitos-mitos mengenai masa nifas, maka dari itu penyuluhan ini harus dapat merubah kebiasaan tersebut, yang dapat dilakukan adalah sebagai berikut :

1. Sistem penyuluhan yang berkala mengenai masa nifas

2. Ibu-ibu harus berperan aktif untuk berkonsultasi langsung kepada tenaga kesehatan

3. Suami dan keluarga harus dapat mendukung kegiatan positf yang dilakukan ibu-ibu pasca persalinan

4. Ibu-ibu diharapkan sering membaca buku-buku mengenai persalinan dan masa nifas

5. Ibu-ibu diharapkan untuk mengikuti penyuluhan-penyuluhan yang dilakukan oleh toko masyarakat sekitar. 


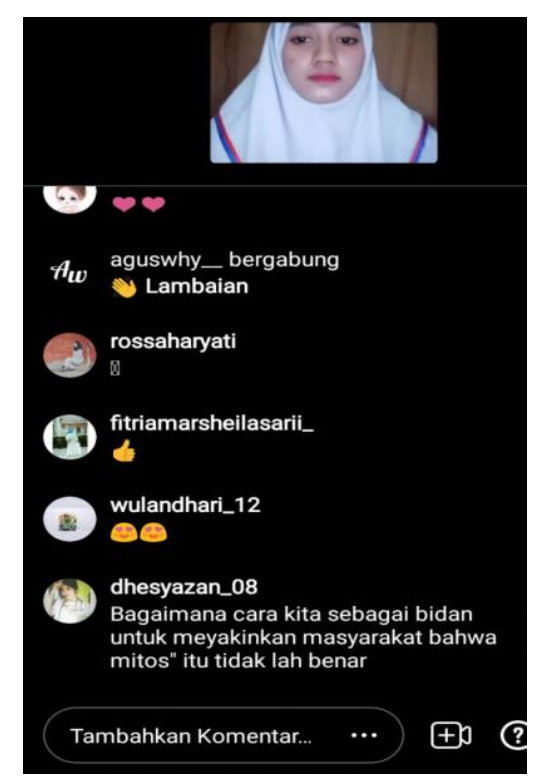

\section{Gambar 3. Penyuluhan Konseling Mitos Dan Fakta Masa Nifas Secara Daring Media Zoom Dan Instagram}

Dengan demikian, kegiatan penyuluhan secara daring diharapkan menjadi titik perubahan yang terjadi pada ibu-ibu yang masih percaya mengenai mitos-mitos masa nifas. Suami dan keluarga diharapkan dapat berperan aktif dan mendukung perubahan baik yang terjadi pada ibu pasca persalinan, dan diharapkan peran serta tokoh masyarakt sekitar untuk mendukung kegiatan penyuluhan-penyuluhan lainnya demi meningkatkan pengetahuan masyarakar mengenai kesehatan.

\section{SIMPULAN}

Kegiatan penyuluhan ini adalah program pengabdian pada masyarakat dalam bidang kesehatan khususnya ibu pasca persalinan. Kegiatan penyuluhan ini dilakukan dengan tiga tahap, tahapan pertama yaitu tahap persiapan meliputi : persiapan rencana yang akan dilakukan pada saat penyuluhan, tahapan kedua yaitu tahap kegiatan meliputi : Pemaparan materi dan konseling ibu-ibu pasca persalinan, dan tahap ketiga yaitu tahap Evaluasi meliputi : Kegiatan peyuluhan berkala dan kesadaran ibu-ibu mengenai pengetahuan masa nifas. Diharapkan penyuluhan ini dapat meningkatkan keingintahuan masyarakat khususnya ibu-ibu pasca persalinan mengenai kesehatan dalam masa nifas dan diharapkan juga para tokoh masyarakat dapat mendukung kegiatan-kegiatan penyuluhan mengenai kesehatan masyarakah, sehingga masyarakat mulai sadar dan mau untuk menerapkan hidup sehat sehingga mengurangi angka kematian akibat ketidaktahuan masyarakat mengenai hidup sehat.Dengan demikian dapat menurunkan angka kematian ibu pasca persalinan dan dapat menciptkan kehidupan yang lebih sehat dan lebih perduli dengan kesehatan setiap anggota masyarakat.

\section{SARAN}

Kegiatan penyuluhan ini tentu saja terdapat banyak kekurangan di berbagai segi. Hal ini akan diperbaiki dan disempurnakan pada kegiatan penyuluhan selanjutnya. Diharapkan semua peserta penyuluhan dapat berperan aktif dalam menyampaikan informasi mengenai permasalahan yang terjadi atau yang dialami, sehingga penyuluhan dapat berjalan dengan baik dan mampu menuntaskan permasalahan yang terjadi pada masyarakat. 


\section{UCAPAN TERIMA KASIH}

Kami mengucapkan terima kasih kepada pihak-pihak yang membantu dalam kegiatan penyuluhan dan pemublikasian artikel ini. Beberapa pihak tersebut diantaranya: (1) Stikes Mitra Adiguna yang telah bersedia menyediakan tempat, (2) Masyarakat Kelurahan Talang Jambe (3) Tokoh masyarakat Kelurahan Talang Jambe (4) semua pihak yang membantu dan tidak dapat disebutkan satu persatu.

\section{DAFTAR PUSTAKA}

Deni Imam, Titih Huriah. 2019. "Pengaruh Pendidikan Kesehatan Tentang Nutrisi Melalui Media Visual Interaktif Terhadap Budaya Pantang Makan (Tarak) Pada Pasien Diabetik Foot Ulcer Di Kabupaten Bojonegoro." Nursing Of Journal Stikes Insan Cendekia Medika Jombang 17(1): 40-49.

Ika Murtiyarini, Yuli Suryanti, Ajeng Galuh Wuyandari. 2020. "Pemberdayaan Kader Dalam Deteksi Dini Komplikasi Masa Nifas Di Desa Penyengat Olak.” 1(1): 5-9.

Jiarti Kusbandiyah, Yuniar Angelia Puspadewi. 2020. "Pengaruh Postnatal Massage Terhadap Proses Involusi Dan Laktasi Masa Nifas Di Malang Jiarti." : 65-72.

Popy Apriyanti, Ria Andreinie. 2020. "Dukungan Keluarga Berhubungan Dengan Frekuensi Kunjungan Family Support Associated With The Frequency Of Postpartum Repeat Visits." Jurnal Ilmiah Permas: Jurnal Ilmiah Stikes Kendal 10(2): 1-4.

Septi Maisyaroh Ulina Panggabean, Siti Erika, Akmalia Purnomo. 2020. "Pendidikan Kesehatan Pentingnya Kunjungan Nifas Kf- 3 Di Kampung Dapur 6 Kelurahan Sembulang Kecamatan Galang Kota Batam Tahun 2020.” Enlightenment Journal (X): 1-6.

Tetti Solehati, Cecilia Destiani Ekautami Putri, Pitria Sri Pujhiyani. 2020. "Pengaruh Pendidikan Kesehatan Nutrisi Pada Tingkat Pengetahuan Ibu Post Partum.” Jurnalkesehatanmasyarakat 7(1).

Yuli Suryanti,Hadisaputro Suharyo, And Sri Achadi Nugraheni. 2020. "The Effect Of Snakehead Fish ( Channa Striata ) Extract On Blood Leukocyte Number And Cesarean Sectio Wound Healing.” : 610. 